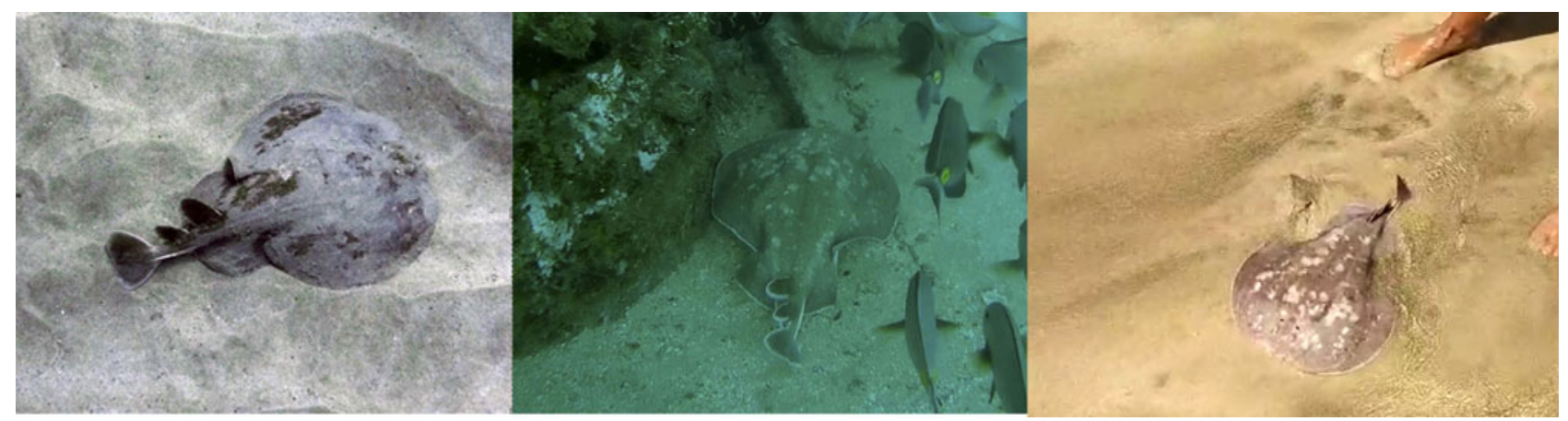

The West African torpedo Torpedo mackayana photographed off Bitxe Rotxa beach, Porto Inglês, Maio Island, in March 2019 (left; Photo: Claire M. Sydeman), April 2021 (middle; frame snapshot from a video: Péricles Neves Silva) and in January 2022 (right; frame snapshot from a video: Jair Rocha).

sighting, an individual of c. $50 \mathrm{~cm}$ total length, was on 16 April 2021 under the pier on Bitxe Rotxa beach, at 11.00 at a depth of 7-8 $\mathrm{m}$, by PNS. The third sighting was of an individual of $<50$ $\mathrm{cm}$ total length, at c. 12.00 on 13 January 2022, also at Bitxe Rotxa beach. The individual was found alive on the sand and was returned to the water by local people and tourists.

This benthic coastal species, with no known pelagic phase in its life cycle, would have had to cross the ocean to reach Cabo Verde, which is c. $600 \mathrm{~km}$ from Senegal. We suspect this species can undertake long pelagic migrations, similarly to that of the great torpedo Tetronarce nobiliana. The conservation status of elasmobranchs in the waters of Cabo Verde is poorly known, and little attention has been devoted to electric rays because they are discarded as bycatch, with no commercial value. Research is required, including tagging, to improve knowledge of their status and distribution, and of any threats. We recommend an examination of a T. mackayana specimen from Cabo Verde, and surveys for this species around Sal and Boavista Islands as they share the same continental shelf as Maio, and similar habitat conditions and distance to the African continent.

We thank Rui Freitas, Peter Psomadakis and the EAFNansen Programme of FAO for their support, insight and expertise.

SARA S. RATÃO (๑ orcid.org/0000-0002-8464-8271, sara.ratao@ fmb-maio.org) and CLAIRE M. Sydeman Fundação Maio Biodiversidade, Cidade do Porto Inglês, Maio Island, Cabo Verde. PérICLES NEVES SILVA (๑ orcid.org/0000-0002-8133-5384) Instituto do mar, Mindelo, Cabo Verde. BERNARD SÉRET (৫orcid. org/0000-0003-2029-8740) Ichtyo-Consult, Igny, France

This is an Open Access article, distributed under the terms of the Creative Commons Attribution licence CC BY 4.0.

\section{Multidisciplinary team highlights the importance of Indigenous and local communities for jaguar conservation}

On 28-29 October 2021, IUCN Netherlands convened the panel The Power of the Jaguar at the Royal Anthropological
Institute's Anthropology and Conservation conference, bringing together anthropologists, biologists, filmmakers and conservationists from across the range of the jaguar Panthera onca to enhance understanding of the role this species plays in human consciousness and existence. In this unique collaboration, nine speakers shared their approaches for understanding and improving relationships between people and jaguars, based on field experiences with cattle ranching in the Brazilian Pantanal, illegal trafficking in Bolivia, human-jaguar conflict and ecotourism in Guyana and Suriname, cultural meanings and cosmologies of Indigenous groups in Amazonia, and approaches for systemic transformations benefiting jaguars and people in Venezuela and Mexico. The speakers illustrated the ways in which Indigenous and local communities are already engaged in jaguar protection, and emphasized the importance of strengthening such collaborations. They also examined how conservation strategies should do more to promote knowledge exchange between the social and natural sciences. The panel discussed two fundamental questions: what are the barriers to effective collaboration, and how have practitioners overcome these to make jaguar research and conservation an interdisciplinary/transdisciplinary pursuit?

The panel noted that jaguar conservationists must be open to alternative approaches beyond traditional conservation science, especially where local forms of environmental knowledge prevail, and that jaguars are threatened by habitat loss and retaliatory killing motivated by fear, material losses, economic motivations and religion. This panel is the beginning of a wider process of exchange and engagement among scholars and practitioners. Practitioners working to protect jaguars must learn from each other as well as from Indigenous and local peoples, whose imagination, stories, knowledge and experiences reflect important lessons this species has taught humanity. This paradigm shift will benefit the jaguar and the diverse peoples with whom it shares its habitat.

Recordings of the Panel's proceedings are available at youtube.com/watch?v=EFFGggFTOXY and youtube.com/ watch? $\mathrm{v}=\mathrm{jU}$ AeeknMKjU. 


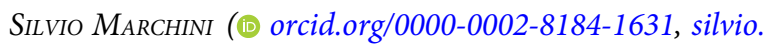
marchini@usp.br) University of São Paulo, Piracicaba, São Paulo, Brazil. Anthony R. Cummings Geospatial Information Sciences, School of Economic, Political and Policy Sciences, University of Texas at Dallas, Dallas, USA. BARBARA M. ARISI (D) orcid.org/0000-0001-7560-9636) Vrije Universiteit Amsterdam, Amsterdam, The Netherlands. CRISTINA ARGUDINVIOLANTE University of Southampton, Southampton, UK. FELIPE SüsSEKIND (10 orcid.org/0000-0002-9899-1230) Pontifícia Universidade Católica do Rio de Janeiro, Rio de Janeiro, Brazil. GLENN H. SHEPARD JR (ㅇ orcid.org/0000-0003-3195-8230) Human Sciences Division, Goeldi Museum, Belém, Brazil. LEWIS DALY (D orcid.org/0000-0002-0542-9397) University College London, London, UK. LILIANA JAUREGUI BORDONES (다이.org/0000-00024020-8696) and LuCIA GUAITA (이 orcid.org/0000-0002-9814-9529) IUCN National Committee of The Netherlands, Amsterdam, The Netherlands. MELISSA ARIAS (10 orcid.org/0000-0003-2612-1540) Interdisciplinary Centre for Conservation Science, Oxford, UK

This is an Open Access article, distributed under the terms of the Creative Commons Attribution licence CC BY 4.0.

\section{Developments in conserving the Javan green magpie Cissa thalassina}

In Indonesia the heavily ingrained and widespread tradition of keeping caged birds, the majority of which are wild-caught, has pushed many species to the brink of extinction. Despite a brief halt of the illegal bird trade during COVID-19 restrictions, overall the trade has not declined, with the Indonesia Ministry of Cooperation and Small \& Medium Enterprises reporting a turnover of IDR 1.7 trillion (c. USD 120 million) in 2020. Alongside offline trade, we have observed that the use of social media and e-commerce sites for illegal bird trade increased during the pandemic.

One species affected by poaching and illegal trade in Indonesia is the Javan green magpie Cissa thalassina, which has undergone severe population declines (van Balen et al., 2013, Bird Conservation International, 23, 91-109). This endemic corvid is restricted to the submontane forests of West and Central Java and is categorized as Critically Endangered on the IUCN Red List. It has a reputation as a high quality master bird: its ability to mimic is used to teach songbird species, used as contestants in singing competitions, a wide repertoire of songs.

In August 2021, Cikananga Wildlife Centre (Yayasan Cikananga Konservasi Terpadu) initiated a multidisciplinary conservation programme for the Javan green magpie in collaboration with Chester Zoo and Manchester Metropolitan University, with funding from the European Association of Zoos and Aquaria Silent Forest Campaign. The first stages of this project comprise a long-term survey of Javan green magpie trade on social media and in physical bird markets, to identify suitable habitats for potential in situ conservation programmes and to engage with local communities in areas where the species may still exist.
Using both social and ecological science techniques, we aim to understand more about this elusive species and the trade that threatens it. Initial findings, alongside those of recent surveys in the Javan Mountains, indicate this species is now rare both in the wild and in trade.

The long-term aim of this project is to protect remaining viable habitat and improve the wild status of the Javan green magpie through measures such as protection of existing wild populations, reinforcement of dwindling populations and reintroductions from conservation breeding programmes into good habitat. To be successful, all of these methods will need to involve local communities. Key aspects of this project will be creating alternative livelihoods and developing pride campaigns, to mitigate the threat of poaching. This project is run alongside Cikananga Wildlife Centre's Cikananga Conservation Breeding Centre, which manages the largest ex situ population of the Javan green magpie, maintaining and maximizing genetic diversity through conservation breeding.

MEIDI YANTO (৫ orcid.org/0000-0001-9170-5804), BERTIE H. FERNS (৫ orcid.org/0000-0003-4536-2032, bertie. ferns@gmail.com), INGE H.M. TIELEN (๑ orcid.org/0000-00031919-0505) and REșiT Sözer Yayasan Cikananga Konservasi Terpadu, Cikananga Wildlife Center, Sukabumi, West Java, Indonesia

This is an Open Access article, distributed under the terms of the Creative Commons Attribution licence CC BY ND 4.0.

\section{Land purchase and forest restoration to conserve the Endangered red panda in Nepal}

The population of the Endangered red panda Ailurus fulgens has been reduced by half in less than 2 decades, predominantly as a result of habitat loss, degradation and fragmentation. The 2016 National Survey of Red Pandas in Nepal found that the species' habitat was fragmented into $>400$ small forest patches, primarily as a result of conversion of forest to farmland and settlements, unsustainable livestock grazing and resource extraction, and infrastructure development. To counter this problem, the Red Panda Network works with local communities by purchasing private land to restore red panda habitat and improve habitat quality and connectivity in the Panchthar-Ilam-Taplejung region in the Kangchenjunga landscape, which has transboundary conservation significance in the eastern Himalayas. Nearly $50 \%$ of the Panchthar-Ilam-Taplejung region has suitable habitat for red pandas but $85 \%$ is unprotected, national forest or private lands.

In 2015, the Red Panda Network initiated habitat restoration initiatives with small-scale reforestation as a part of its community-based red panda conservation programme. This initiative developed into a flagship campaign known as Plant A Red Panda Home in 2020, which reforests core habitat and connects fragmented forest through land purchase and tree planting to create a wildlife corridor to 